\title{
ІНСТРУМЕНТИ ЕФЕКТИВНОГО ОНЛАЙН-НАВЧАННЯ ІНОЗЕМНИХ МОВ В УМОВАХ ДИСТАНЦІЙНОЇ ОСВІТИ
}

\author{
Стрельченко Л. В., Дудіна О. В.
}

\section{ВСТУП}

Виклики, 3 якими стикається людство останніми роками, стимулюють бути обізнаними в різних галузях знань, здобуваючи інформацію з різноманітних джерел. Найбільш поширеним, доступним i пізнавальним $\epsilon$ Інтернет. Ефективність використання Інтернет у здобутті студентами вищої освіти доведено провідними світовими університетами: Відкритим університетом Великої Британії, Оксфордським, Кембриджським та університетами США i європейських країн. Особливо варто відмітити неперевершену роль Інтернет у навчанні іноземних мов i, зокрема, англійської мови. В умовах швидкої глобалізації викладач іноземної мови постійно відчуває необхідність удосконалення вмінь і навичок роботи з Інтернет ресурсами, застосування яких позитивно впливає на якість навчання та розвиток іншомовної компетентності студентів у закладах вищої освіти. В Україні вчителі загальноосвітніх шкіл, викладачі навчальних закладів вищої освіти підвищують кваліфікацію, навчаючись на онлайн-курсах $з$ використання Інтернет ресурсів. Після їх завершення вони відчувають особливе бажання до застосування нових знань у навчальному процесі. Але, згідно з опитуванням Educause Survey у 2017 році, лише 9 відсотків викладачів уважає за краще навчати студентів у повністю онлайн-середовищі ${ }^{1}$. Більшість із них дотримуються традиційних форм навчання.

У професійній підготовці майбутніх викладачів іноземних мов у вітчизняних університетах недостатньо приділялася увага методиці дистанційного навчання, розробленню цілісних курсів вивчення мови на основі, наприклад, платформи Google classroom, оцінювання результатів навчання студентів, організації зворотного зв'язку. Опитування старшокурсників свідчить, що майже ніхто 3 майбутніх викладачів не має на меті стати чудовим учителем іноземної мови в Інтернет просторі, хоча завдяки навчанню в університетах студенти

\footnotetext{
${ }^{1}$ Pomerantz J.D., Brooks C. Study of Faculty and Information Technology / Educause Survey. ECAR, October, 2017. URL: https://library.educause.edu/resources/2017/10/ecarstudy-of-faculty-and-information-technology-2017.
} 
набувають навичок роботи з Інтернет ресурсами й мають досвід роботи в онлайн класах. В умовах пандемії коронавірусу, коли навчальні заклади всіх рівнів перейшли на дистанційну освіту, викладачі іноземних мов використовують Інтернет ресурси, які створенні спеціально для підтримки закладів середньої, вищої освіти й окремих учителів у відповідь на поширення Covid-19. Наприклад, ресурсний банк (the Resource bank) має на меті поділитися порадами досвідчених освітян $з$ усього світу, щоб допомогти використовувати потенціал дистанційної освіти як важливу частину планування наступності в ці складні часи ${ }^{2}$.

Метою дослідження $€$ визначення основних інструментів ефективного он-лайн навчання іноземних мов в умовах дистанційної освіти.

Для досягнення мети й виконання поставлених завдань використано комплекс таких методів, як аналіз, узагальнення, контент-аналіз (для визначення стану розробленості досліджуваної проблеми у вітчизняних і зарубіжних працях учених і дослідників) і порівняння, інтерпретація, класифікація, систематизація (для виявлення новітніх засобів для дистанційного навчання та особливостей використання онлайн інструментів у вивченні іноземних мов). Метод узагальнення використано для формування висновків, виокремлення засобів перевірки якості навчання й оцінювання знань студентів 3 іноземних мов в умовах дистанційного навчання. Бесіда, спостереження, опитування, обговорення актуальних питань 3 дистанційного навчання іноземних мов під час конференцій, дискусій 3 британськими викладачами на міжнародних форумах i курсів - для отримання первинного емпіричного матеріалу з метою виявлення особливостей застосування онлайн інструментів у вивченні іноземних мов.

У дослідженні питання підвищення кваліфікації викладачів іноземних мов через онлайн середовище важливою $\epsilon$ інтерпретація таких термінів:

1. Система управління навчанням (Learning management system - LMS) - це платформа, яку використовує заклад освіти як систему управління навчанням 3 високою швидкістю, але здебільшого лише для оперативних функцій управління курсами, таких як циркуляція інформації, наприклад, навчальний план, роздатковий матеріал i завдання. Функціональне управління курсами LMS $є$ зручним для навчання, контролю й оцінювання кожного виду роботи студентів.

${ }^{2}$ Swiftly Moving to Teaching Online - Resource Bank / National Institute for Digital Learning. Dublin, 2020. URL: https://www.dcu.ie/nidl/resources/Swiftly-Moving-OnlineCoronavirus.shtml. 
2. GoogleDocs (GoogleDrive) - це набір хмарних програм, який може застосовуватися для спільної роботи, включає текстовий процесор, редактор зображень, програмне забезпечення для електронних таблиць і презентацій і платформу опитування ${ }^{3}$.

3. Модуль (Module) є найпоширенішою одиницею організації дистанційного навчання. Викладачі використовують модулі для підбору матеріалів курсів за темами. Вони впорядковуються послідовно й містять усі навчальні матеріали та навчальні заходи для конкретної теми чи підрозділу.

4. Мікролекторне відео - це мікроелементи, короткі (до 6 хвилин), підготовлені викладачами відео, розроблені за допомогою структурованого формату для надання ефективних пояснень окремої ключової концепції або певного набору навичок ${ }^{4}$.

5. Асинхронний (Asynchronous). Більшість онлайн курсів $\epsilon$ асинхронними, тобто студенти не всі разом в один час на занятті, а заняття взагалі може не проводитися в режимі реального часу. Натомість студенти можуть виконувати завдання, коли їхні графіки дозволяють.

\section{1. Ефективне використання наборів інструментів у вивченні іноземних мов для дистанційного навчання}

Онлайн заняття зазвичай проводяться за обраними установою системами управління навчанням, тобто платформами, які включають комунікацію, поширення змісту навчання й інструментів оцінювання для полегшення процесу викладання та навчання. Різні системи управління навчанням можуть відрізнятися один від одного за певними специфічними особливостями, але зазвичай можна знайти загальні елементи та функції: журнал для запису успішності студентів, вебсторінки або сайти, які дають змогу переміщувати текст, відео чи посилання на інші джерела, інструменти оцінювання, такі, щоб студенти могли здати на перевірку виконані роботи, скласти вікторину чи іспит, форуми для обговорень, які дають можливість брати участь у бесідах з викладачем і в міжстудентському спілкуванні.

Сучасний викладач іноземної мови, який застосовує дистанційне навчання, повинен публікувати щотижневе оголошення, щоб забезпечити огляд теми наступного тижня або результати роботи попереднього тижня або й те, й інше; відповідати на питання,

${ }^{3}$ Hedge S. Teaching with GoogleDocs / A Blog from GradHacker and MATRIX: The Center for Humane Arts, Letters and Social Sciences Online. Washington, D.C., 2013. URL: https://www.insidehighered. com/blogs/gradhacker/teaching-googledocs.

${ }^{4}$ Welcome to ACUE's online teaching toolkit / Association of College and University Educators. New York, 2020. URL: http://acue.org/online-teaching-toolkit/. 
розміщені на онлайн форумі з питаннями та відповідями або ті, які надіслані електронною поштою; дотримуватися часу й дати занять 3 дисципліни, публікувати короткі автентичні відео та відео 3 поясненням помилки всієї групи щодо теми чи завдання; вчасно оцінювати та повертати роботи студентів; проводити обговорення зі студентами в онлайн дискусіях. Але викладач іноземних мов має таку перевагу в організації дистанційного навчання, як гнучкість. Це і $є$ однією з основних причин, чому багато викладачів і студенти обирають відвідування онлайн занять.

Сьогодні в університетах України широкого використання під час вивчення іноземних мов набирає текстовий процесор (або документ (GoogleDocs). Документ є схожим на інтерфейс Microsoft Word, але він має кілька захопливих інших функцій. Найважливішою особливістю GoogleDocs для аудиторної практики $\epsilon$ те, що студенти можуть співпрацювати над одним документом у режимі реального часу. GoogleDocs має функцію коментування тексту, а також вікно чату зліва на екрані. Документи можна створити прямо у власному браузері відразу або завантажити з комп'ютера. Нарешті, уся робота в документі автоматично зберігається в хмарі, тому викладач іноземних мов має можливість повертатися до того ж документа стільки разів, скільки потрібно, не турбуючись про втрату виконаної роботи.

Зручною функцією є створення власного календаря публічних подій. Це можна зробити за допомогою плагіна Google Forms під назвою Form Director. Календарі корисні для встановлення розкладу курсу або конференції. Студенти можуть імпортувати календар викладача в особистий календар (Google Календар - cepвic Microsoft також забезпечує функціональність календаря, Nextcloud продуктивний комплекс з убудованим календарем $)^{5}$.

GoogleDocs є зручним для викладача філології. Ось кілька ідей щодо того, як застосовувати його під час дистанційного вивчення іноземних мов. Наприклад, викладач просить кожного студента завантажити свою роботу та поділитися нею 3 групою. Студенти можуть легко коментувати роботу один одного, а вбудований чат дає їм можливість спілкуватися один із одним у процесі обговорення. Це чудово для того, щоб студенти проводили семінарські заняття після занять, але це можна застосовувати, навіть якщо вони сидять поруч в одній аудиторії.

${ }^{5}$ Creating an Online Community, Class or Conference - Quick Tech Guide / Google Docs. 2020. URL: https://docs.google.com/document/u/0/d/1ux31TnUTpzZRuvxE3rAs SQ4Ihub96S8_OYECNh8wv-A/mobilebasic\#heading=h.xpjunkqt5jka. 
Успішним показує себе GoogleDocs у таких видах роботи, коли викладач іноземних мов перед заняттям пропонує студентам створити невелику кількість запитань після читання тексту в спільному документі, а далі використовує ці питання для створення дискусії в групі. Можна також попросити студентів відповісти на питання один одного письмово. Цей документ залишатиметься загальнодоступним, тому студенти можуть посилатися на нього під час підготовки до іспитів або написання есе. Застосування GoogleDocs викладачами іноземної мови уможливлює створення тематичних конференцій i презентацій.

Дуже зручним для викладача під час проведення онлайн занять $€$ використання створеного набору корисних посилань або набору ключових термінів. Це уможливлює швидке додавання документів, сприяє тому, що цей документ може вдосконалюватися та розширятися протягом семестру або курсу, оскільки викладач і студенти можуть знаходити більше цікавих сайтів. Треба лише почати документ у перший день курсу й подивитися, де він закінчиться.

Викладач іноземних мов може опублікувати деякі слайди чи нотатки лекцій y GoogleDocs i запропонувати студентам робити нотатки в спільному документі. До кінця семестру студенти матимуть колективний i доступний запис курсу, яким можна поділитися 3 майбутніми слухачами.

Для створення курсу, дисципліни чи конференції найпростішими у використанні для викладача іноземних мов $є$ хмарні програми, такі як Google або Zoho. Можливий Blogger для публікації блогів або GMail для читання електронної пошти. Перевага полягає в тому, що викладач може багато дечого зробити, не витрачаючи на це взагалі ніяких грошей, недолік - часто є обмеження на те, що ви можете зробити 3 безкоштовними онлайн додатками.

Застосування веб-хостингу в дистанційному навчанні іноземних мов $\epsilon$ корисним під час створення облікового запису за допомогою сервера веб-хостингу (наприклад, Reclaim Hosting), викладач використовує їх внутрішню панель програм (зазвичай cPanel) для встановлення та запуску власних хмарних програм ${ }^{6}$. Перевага полягає в тому, що немає обмежень на власні програми, але недоліком $\epsilon$ те, що вони не $\epsilon$ завжди безкоштовними. Використання хмарного хостингу дає можливість створювати обліковий запис за допомогою хмарної служби (наприклад, Digital Ocean), а потім створювати та запускати веб-доступний

${ }^{6}$ Creating an Online Community, Class or Conference - Quick Tech Guide / Google Docs. 2020. URL: https://docs.google.com/document/u/0/d/1ux31TnUTpzZRuvxE3rAs SQ4Ihub96S8_OYECNh8wv-A/mobilebasic\#heading=h.xpjunkqt5jka. 
контейнер для власної програми. Перевага полягає в тому, що викладач іноземних мов може запускати більші та складніші програми, але недоліком $є$ те, що це може коштувати дорожче й буде важчим налаштування.

Працюючи дистанційно зі студентами, викладач пропонує їм розмістити свої дипломні роботи на групових семінарах. Це заохотить студентів коментувати висловлювання, ставити питання й обговорювати представлені ідеї. Потім можливим $є$ опублікування такого документа у Twitter, підключивши до обговорення ширшу аудиторію. Застосовуючи той же GoogleDocs для створення величезної анотованої бібліографії, кожен студент має можливість унести два чи три власні джерела, і до того часу, поки всі поділяться власними дослідженнями, у групі буде груповий документ із десятками анотованих джерел.

Розвиток комунікативної компетентності студентів під час вивчення іноземних мов в умовах дистанційного навчання $\epsilon$ найбільш дискусійною темою. Але досвід колег із багатьох національних університетів показує, що це питання вирішується шляхом колективного спілкування студентів зі застосуванням функції чату та співпраці над груповими проектами чи в групових дискусіях.

Під час онлайн навчання іноземної мови викладач має можливість активно застосовувати асинхронні методи дискусій у групі, тобто Інтернет форуми, тематичні дискусії, що $\epsilon$ найбільш широко застосовуваним режимом асинхронного обговорення зі студентами. Тут використовується система управління навчанням (наприклад, Google Clasroom), блог або інша платформа. Викладачі можуть дати чіткі вказівки студентам, коли їм подати необхідні повідомлення та відповіді (дата й час), про що мають писати студенти (навіть для відкритих відповідей, корисною буде підказка або вказівки щодо того, який матеріал варто студенту включити у відповідь), які за обсягом повинні бути повідомлення студентів, якщо буде оцінювання (скільки речень, слів чи абзаців). Звичайно якщо очікується, що студенти коментуватимуть один одного, це варто зазначити в указівках до обговорення/дискусії. Така діяльність студентів може відбуватися індивідуально, викладач може подати завдання в системі управління онлайн навчанням у дописі.

Такий вид роботи, як «обговорення 3 приятелями або приятельське листування», може бути ефективним, якщо призначити кожного студента бути учасником дискусії та писати листи (вести регулярний діалог про навчальний матеріал за допомогою набору синхронних та асинхронних методів, перевіряти завдання). Якщо викладач іноземних мов використовує систему приятелів, тобто розбиває студентів на 
групи для дискусій, то для організації такого виду роботи й успішної реалізації мети та завдань необхідні чіткі вказівки й інструкції щодо частоти і тривалості роботи студентів у групах чи в парах, описати конкретні результати, які викладач очікує від кожного (наприклад, ставити інструктору запитання щодо матеріалу, виправляти одногрупників/коментувати окремі роботи). Викладач може запросити скриншот обміну текстом чи відео чату між студентами.

Приятелі-одногрупники можуть робити як асинхронні, так i синхронні дії разом; важливо, що вони можуть визначити найкращі інструментарії для себе, за допомогою яких можна проводити власні зустрічі. Це допоможе створити гнучкість для студентів, які мають різні види доступу, але також створить автоматичну групу одногрупників, що допомагає під час швидкого виконання завдань в онлайн режимі. Така діяльність, як обговорення, може відбуватися в парній роботі, у невеликих групах, за допомогою телефонного дзвінка, відео чату, програмами обміну повідомленнями, електронною поштою. Викладач може надсилати завдання особисто, електронною поштою, системою управління навчанням/онлайновою публікацією.

Старший інструктор із дизайну університету Північної Аризони, який викладає онлайн курси, Ф. Дарбі стверджує, що Інтернет курси 3 вивчення іноземної мови мають репутацію нудних і сухих завдань 3 читанням і письмом, тому студенти, які прагнуть вивчити мову швидше, хочуть опинитися в середовищі спілкування або особисто 3

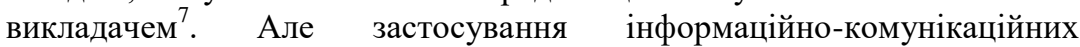
технологій дає можливість зробити дистанційне вивчення іноземної мови більш цікавим i розвивати комунікативну компетентність студентів завдяки широкому доступу до автентичних текстів, завдань, опитувань, дискусій, форумів і різних видів спілкування. Способи навчання іноземної мови змінюються в наш час, зовнішній вигляд завдань i їх подача студентові впливає на бажання вчитися та приносить їм і викладачу задоволення, а отже, і впливає на активність.

Сьогодні викладач іноземної мови має серйозно задуматися над тим, як виглядають його онлайн курси. Розмірковуючи про візуалізацію онлайн класу, викладач має можливість звернутися до інформативних тематичних веб-сайтів, використовувати онлайн книги, журнали, підручники 3 іноземної мови. В умовах дистанційного навчання важливим є дизайн онлайн курсів. Тут на допомогу приходять функції платформ навчання (уставити відповідні зображення, розбити довгі шматки тексту на підзаголовки та збільшити пробіли між абзацами, додати мініатюрні відео з YouTube й інших ресурсів).

Американський учений Ф. Дарбі наголошує, що в багатьох навчальних установах $€$ медіа-дизайнери, які можуть допомогти 
викладачеві звернутися або до навчального центру кампусу, або до співробітників служби підтримки LMS; Інтернет-курс, який є візуально привабливим, допомагає студентам брати участь у заняттях частіше та змістовніше ${ }^{7}$. Звичайно, викладач іноземних мов під час дистанційного навчання має продумати, щоб усі наочні матеріали були доступними для всіх студентів, тому необхідно використовувати інструменти форматування в текстовому редакторі.

Розвиток комунікативних навичок студентів під час вивчення іноземних мов дистанційно за умови ефективної модерації, онлайн дискусії можуть бути основним видом роботи в групі. Це $є$ потужною стратегією вивчення іноземних мов, що дає однаково рівну можливість кожному студентові активно брати участь у навчанні, тестуванні та застосуванні вже набутих знань, а не пасивно приймати знання від викладача. Такий тип взаємодії може допомогти студентам вивчити нові ідеї та зміст на глибшому рівні, сприяти розвитку навичок спілкування та співпраці в групі. Існує кілька різних типів онлайн дискусій в освітніх контекстах, включаючи ${ }^{8}$ :

- питання та відповідь: студенти можуть отримати допомогу 3 будь-яких питань або проблем, із якими вони можуть зіткнутися від викладача й один одного;

- вирішення проблем, аналіз чи обмін ідеями: студенти та викладач обговорюють спільні проекти, лекції, проводять сеанс мозкового штурму або беруть участь у подібних заходах;

- соціальний: студенти потребують платформи та спілкування, щоб вони змогли познайомитися один із одним на більш особистісному рівні. Це може допомогти студентам сформують довіру й удосконалити співпрацю та групову роботу.

Розподіл групових завдань серед студентів може підтримати амбіції та впевненість студентів у своїх знаннях і їх розширення 3 теми дискусії. Це також може скоротити час, витрачений на маркування окремих матеріалів. Підкасти й відео можуть бути також застосовані під час дискусій і їх обговорення.

Викладач іноземних мов повинен установити обмеження часу для підготовленого відео чи підкастів у хвилинах. Це має створити баланс між наданням студентам можливості не пропустити важливі поняття й

${ }^{7}$ Darby F. How to be a better online teacher. Advice Guide / The Chronicle of Higher Education. Washington, D.C., 2020. URL: https://www.chronicle.com/interactives/adviceonline-teaching.

${ }^{8}$ McIntyre S. Learning to teach online. Conducting effective online discussions / COFA Online. Australian Learning and Teaching Council, 2018. URL: https://ltto.unsw.edu.au/wp-content/uploads/2018/03/Discussions_LTT On.pdf. 
досягти результатів навчання та часовим обмеженням як для оцінювача (викладача), так і для студентів.

Плануючи онлайн дискусії, викладач іноземних мов має необхідність зробити дискусії актуальними та корисними, тоді студенти будуть повністю зацікавлені й залучені. Викладач має переконатися, що студенти мають сформовану технічну компетентність. Щоб рівноправно брати участь, студенти повинні мати глибоке розуміння технології, у якій мають відбуватися дискусії. Важливим моментом під час організації онлайн дискусій є академічна суворість, яка необхідна в різних дискусіях. Наприклад, менш формальна мова може бути доречною, але для представлення ідей або планування можуть знадобитися більш формальні тони.

Онлайн дискусії та навіть конференції можна проводити застосовуючи декілька програм, які дають можливість викладачу керувати цілими подіями, піклуючись про деталі, такі як планування динаміків і реєстрація студентів у дискусії: EventZilla - безкоштовний варіант програми для проведення дискусій, Open Conference Systems доступні для деяких хостинг-сервісів, Mobilizon - децентралізована платформа подій 9

Викладач іноземних мов може застосовувати мікролекторні відео в системі управління навчанням, створюючи відео, яке може бути як екскурсія для студентів в онлайн середовищі. Для успішного застосування мікролекторних відео в групі, викладач має врахувати такі корисні фолії для відео, які включити у свій тур: 1) як підготуватися до онлайн навчання, 2) указівки щодо орієнтованого курсу; 3) очікування на спілкування щотижня.

Система веб-конференцій за попередньо запланованим часом $\epsilon$ одним зі способів залучення до комунікації в онлайн курсах. Під час синхронної сесії викладач іноземних мов використовує програмне забезпечення для веб-конференцій i запрошує всіх студентів приєднатися в заздалегідь запланований час. Програмне забезпечення для веб-конференцій університету - Zoom - можна використовувати на ноутбуках, настільних комп'ютерах, планшетах, смартфонах, що дає студентам багато способів доступу до заняття.

Zoom пропонує вебінари та наради. Обидва формати дають змогу взаємодіяти зі студентами, але вони мають деякі відмінності. Викладач іноземних мов планує зустрічі в Zоom кількома різними способами: за допомогою інтерфейсу Zoom, календаря Google або в межах Canvas.

${ }^{9}$ Creating an Online Community, Class or Conference - Quick Tech Guide / Google Docs. 2020. URL: https://docs.google.com/document/u/0/d/1ux31TnUTpzZRuvxE3rAs SQ4Ihub96S8_OYECNh8wv-A/mobilebasic\#heading=h.xpjunkqt5jka. 
Організатор надає посилання на віртуальний зал Zoom на веб-сайті Canvas. Викладачеві доведеться моделювати та навчати своїх студентів базових етикетів онлайн зустрічей. Для цього необхідно попросити студентів увімкнути свої камери, подивитися в камеру, щоб установити очний контакт, коли вони розмовляють, вимкнути свої мікрофони, коли вони не роблять внесок у дискусію, використовувати поле чату лише для конструктивних коментарів. Викладач, як правило, планує ролі для студентів, не дозволяючи хаосу в дискусії. Для викладача буде менш напружений досвід управління аудиторією, якщо він делегує певні аспекти управління онлайн простором своїм студентам, тобто попросить одного технічно навченого студента контролювати чат, щоб допомогти своїм одногрупникам вирішувати проблеми з використання Zoom.

\section{2. Креативні методи перевірки якості вивчення іноземних мов під час Інтернет навчання}

3 широким використанням Інтернет у здобутті студентами вищої освіти змінилися методи оцінювання результатів їх навчання в університетах. Сучасні технології в умовах дистанційної освіти набирають швидкий темп розвитку, щоб допомогти викладачам в успішній реалізації навчання іноземних мов. Студенти також не лише знайомі із цими технологіями, вони очікують, що передовий викладач буде використовувати їх у всіх аспектах викладання, у тому числі й в оцінюванні знань і рівня засвоєного матеріалу.

Якість дистанційного вивчення іноземної мови можна перевірити за допомогою E-xcellence, який $\epsilon$ важливим інструментом удосконалення знань, відкритості й гнучкості для покращення роботи університетів у режимі онлайн. Цей інструмент містить посібник для оцінювання поточних показників, пропонує інструкції щодо вдосконалення навчання. E-xcellence $\epsilon$ довідковим інструментом для університетів, які застосовують змішане навчання на інституційному рівні.

E-xcellence сприяє якісним аспектам сучасної онлайн, відкритої та гнучкої освіти, $\epsilon$ партнером університетів, а також асоціацій із забезпечення якості, які надають висновок про найсучаснішу відкриту освіту. Лейбел E-xcellence спрямовано на поліпшення доступності, гнучкості, інтерактивності та персоналізації в закладах вищої освіти. Натепер два університети і три факультети мають етикетку E-хcellence до 2022 року, а ще чотири університети тримають лейбел до 2021 року ${ }^{10}$.

${ }^{10}$ E-xcellence in e-learning. Associates in Quality / EADTU. Maastricht. The Netherlands, 2009. URL: https://e-xcellencelabel.eadtu.eu/. 
Під час дистанційного навчання викладач іноземних мов планує досягти такої мети оцінювання рівня знань студентів, як неформальну (informal), формувальну (formative), підсумкову (summative), формальну (formal). До неформальної мети оцінювання належить перевірка домашнього завдання, вікторини, нестандартні завдання, спостереження в класі тощо. Формувальна мета оцінювання полягає в тому, що викладач дає студентам змогу ідентифікувати чи бути залученими у своє навчання. Формувальна мета полягає в тому, що викладачі мають відповідально навчати та допомагати студентам оцінити свій прогрес. Підсумкова мета оцінювання, яку планує викладач іноземних мов, полягає в оцінюванні того, чи виконані навчальні завдання, в загальній оцінці навчання, у детальному спостереженні в групі, створенні доповідей. Формальна мета оцінювання, яку планує викладач іноземних мов, може реалізуватися у вигляді курсової роботи, підсумкового контролю, стандартизованих завдань, відповідних критеріїв і норм.

Під час дистанційного навчання викладач іноземних мов використовує як формувальне (formative), так і підсумкове (summative) оцінювання. Підсумкове оцінювання здійснюється за допомогою підсумкових, семестрових i завершальних іспитів. Але не менш важливим $€$ формувальне оцінювання в умовах дистанційного навчання, оскільки допомагає краще зрозуміти повчальні потреби студентів i вказує на, що потрібно зосередити увагу для покращення результатів навчання. Викладач іноземних мов має продумати, як застосувати регулярно формувальне оцінювання в онлайн курсі. Варто звернути увагу на креативність студентів під час дистанційного навчання, наприклад, під час оцінювання підкастів, створених студентами під час вивчення іноземних мов, викладач має оцінити ще й технічні аспекти підкастів/відео та їх контент. Це не відрізняється від основ створення рубрики для презентацій, де ії зміст впливає загалом на оцінку, але існує більший обсяг можливостей для студентів, щоб створити технічно блискучий підкаст/відео з невеликою академічною цінністю. У цьому разі викладач іноземних мов оцінює зміст підкастів і презентацій, вирішує, чи буде індивідуальний або груповий характер роботи впливати на оцінювання. Підкасти - це цікавий спосіб спілкування зі студентами, ефективний інструмент, який допомагає вивчити глибше розуміння та значення професійних понять іноземною мовою.

Методи оцінювання знань студентів під час дистанційного навчання повинні обов'язково підтримувати навчання студентів i доводити інформативність для постійного оцінювання викладача. Серед найпоширеніших методів оцінювання онлайн $\epsilon$ вікторини, заповнення пропусків (Fill-in-the-Blank Cloze Activity), з'єднання частин речення 
або визначення (Matching Questions), повідомлення на форумі, експертна оцінка й огляд, результати опитування/вікторини в режимі реального часу, вихідні картки (Exit cards/minute papers), онлайн модулі навчання.

Одна 3 переваг вікторин полягає в тому, що вони короткі та прості в оцінюванні. За допомогою цифрово розроблених вікторин порядок запитань і варіанти можна рандомізувати, тож вікторина кожного учня унікальна.

Заповнення пропусків (Fill-in-the-Blank Cloze Activity) є швидким, коротким інструментом оцінювання відповідей.

Онлайн модулі навчання або платформи оцінювання студентів (наприклад, ProProfs student assessment software) $\epsilon$ потужними інструментами, які пропонують викладачам різноманітні функції для створення онлайн тестів чи іспитів ${ }^{11}$. Серед їх зручних функцій викладач іноземної мови може автоматизувати різні методи оцінювання, відслідковувати хід навчання своїх студентів та отримувати попередні звіти для виявлення прогалин у знаннях. Оцінки, виставлені за допомогою програмного забезпечення для оцінювання студентів, можна відправити географічно розсіяній аудиторії студентів.

Вихідні картки (Exit cards) - це перевірка засвоєного матеріалу у вигляді питання-відповідь завдань, які студенти повинні виконати протягом останніх 5 чи 10 хвилин заняття. Вихідні картки швидко оцінюються, оскільки містять не менше ніж кілька речень, але вони можуть допомогти викладачу іноземних мов оцінити розуміння студентів засвоєного матеріалу за короткий проміжок часу. Цифрові вихідні картки можуть збиратися на електронну пошту або за допомогою внутрішньої системи обміну повідомленнями системи управління навчанням.

Якщо викладач іноземних мов потребує ефективного оцінювання студентів за допомогою програми TrainingCheck, то він може обрати будь-яку з 18 готових до використання систем оцінювання, вибираючи ключові сфери оцінювання, такі як реакція учасника (креативність, вчасно зроблене завдання), знання й уміння, вплив на майбутню професію. За допомогою програми TrainingCheck викладач може швидко та легко додати або створити власний варіант, використовуючи 16 різних типів запитань (кілька варіантів вибору, рейтинг тощо) або імпортуючи оптимізовані запитання з широкої бібліотеки запитань.

${ }^{11}$ Student Assessment Software. Easily create and share online tests and assessments / ProProfs. Quiz Maker. 2005-2020. URL: https://www.proprofs.com/quiz-school/ solutions/student-assessment-software/. 
Також викладач іноземних мов може отримати докладні звіти i статистику для кожного оцінювання студентів за допомогою інструменту оцінювання студентів ProProfs i легко відслідковувати результати окремих студентів, а також за груповими показниками. Він також має можливість переглядати деталі, такі як загальна кількість зроблених спроб, попередні оцінки, кількість неправильних чи правильних спроб тощо. За допомогою статистики викладач аналізує загальний рівень складності питань, загальний час, необхідний для завершення оцінювання, і напрями вдосконалення. По завершенню оцінювання викладач іноземних мов з легкістю може завантажити звіти у форматі CSV або Excel.

Під час дистанційного навчання викладач іноземних мов не може побачити реакцію студентів, їхні обличчя, коментарі й емоційний стан студента під час отримання та виконання завдання. Особливість онлайн навчання полягає в тому, що викладач не можете чітко інтерпретувати реакції студентів. Студенти можуть бути творцями власного досвіду навчання. Ключовою частиною цього може бути те, що викладач приймає їхні відгуки й уносить зміни в навчання. Регулярно викладач іноземних мов має можливість отримати відгук студентів. Щоб досягти цього, після виконання завдань можна додати кілька основних питань, щоб допомогти перевірити, чи студенти отримують те, що їм необхідно. Приклад методів збирання зворотного зв'язку може бути опитування, запитання електронною поштою, обмін повідомленнями, вебінари, збирання даних з платформ, стенд-ап або живі сесії тощо. Викладач має реально дивитися на онлайн навчання й чітко розуміти, що він може вдосконалити з відгуків студентів, а що залишити так, як є. Це, у свою чергу, позитивно вплине на підсумкове оцінювання. Підсумкові оцінки використовуються для перевірки, наскільки успішно студенти досягли бажаних цілей навчання. Підсумкові оцінки часто оцінюють результативність роботи студентів на основі конкретного орієнтиру чи очікування досягнення. Наприклад, стандартизовані тести, які використовує майже кожен викладач іноземних мов, $€$ сумарними оцінками.

Діапазон підсумкових оцінок не настільки великий, як для формаційних оцінок: стандартизовані тести, середньострокові та підсумкові іспити, які часто становлять значну частину оцінки студента в курсі, підсумкові проєкти, які можуть мати формувальний компонент. Проєктні, дослідницькі, курсові, дипломні роботи й усні іспити - усі вони спрямовані на оцінювання кумулятивного навчання студента протягом курсу навчання.

Загалом підсумкові оцінки дають короткий огляд усього, що студент засвоїв під час кульмінації цього навчання, закінчення курсу, 
закінчення семестру, навчального року чи закінчення програми навчання.

Якщо оцінка, здобута студентом, $€$ неформальною та формувальною, у викладача іноземних мов може бути набагато більше можливостей для визначення альтернатив традиційним оцінюванням у групі. Значна частина цього може бути асинхронною, але, можливо, викладач іноді хочете провести деяку неофіційну формувальну оцінку в режимі «один на один» або синхронно. Неофіційне та формальне оцінювання часто не має чітких строків або маркування робочих процесів, що забезпечує їх гнучкість.

Формальне та підсумкове оцінювання може бути складнішим i вимагатиме більшої підготовки, щоб студенти були знайомі з обраним викладачем методом. Значну частину завдань ще можна зробити асинхронно: програмне забезпечення для плагіату може допомогти визначити справжню роботу й маркування, презентації можна записувати з подальшими запитаннями за допомогою коротших сеансів спілкування в чаті/прямому ефірі.

Онлайн навчання використовує потужність технологій, щоб допомогти студентам взаємодіяти 3 навчальним матеріалом новими i творчими способами. Під час розроблення оцінювання викладач іноземних мов має можливість додавати аудіо, відео, соціальні медіа, вікі для спільної роботи, методи творчих досліджень тощо, щоб допомогти студентам формувати/розвивати цінні компетентності, які вони можуть використовувати під час майбутньої професійної діяльності й у повсякденному житті. Крім того, викладач іноземних мов може скористатися зручними та далекосяжними інструментами спілкування, щоб допомогти студентам зв'язатися між собою. Оцінювання більше не потребує сухих іспитів, яких бояться студенти; скоріше, це може бути можливість для захопливих, зосереджених напрямів роботи в реальній команді, вирішення проблем і завдань.

\section{ВИСНОВКИ}

Ефективне застосування онлайн інструментів у навчанні іноземних мов вимагає практичних умінь і навичок, а також терпіння як від викладача, так i від студента. Розвиток інформаційнокомунікаційної компетентності шляхом використання можливостей Інтернет ресурсів у різному вигляді позитивно впливає не тільки на вивчення іноземних мов, а й загалом на якість підготовки студентів у закладах вищої освіти. Чітке розуміння мети та актуальності онлайн навчання сприяє розвитку стратегій викладання іноземних мов в умовах дистанційної освіти. 
Застосування системи управління навчанням сприяє розвитку зацікавленості студентів у засвоєнні іншомовного матеріалу, їхній творчості, створює інноваційний оригінальний контент, що полегшує реалізацію мети та завдань занять.

Викладач іноземних мов, оцінюючи рівень знань студентів, має налаштовувати їх на вдосконалення результатів навчання та мотивацію вивчення іноземних мов. Програмне забезпечення для оцінювання роботи студентів дає викладачам змогу використовувати зображення й відео в запитаннях, а також додавати завдання, такі як, наприклад, правда-неправда, заповнення пропусків, множинного вибору та незавершених питань. Онлайн інструменти оцінювання уможливлюють змінити фонове зображення оцінки, назви теми, надати кольорову схему тесту для оцінювання робіт студентів, а після завершення оцінювання дають змогу переглядати статистику оцінок 3 теми чи дисципліни.

Практичне значення використання Інтернет інструментарію в навчанні студентів університетів іноземних мов полягає в застосуванні набутої інформаційно-комунікаційної компетентності в професійній діяльності, бути конкурентоспроможним на ринку праці. Цьому допомагає автентичне оцінювання. Поєднання традиційних та онлайнових оцінок під час вивчення іноземних мов використовується як в аудиторії, так і поза нею. Більша кількість цифрових даних у режимі реального часу та зворотного зв'язку дає викладачу іноземних мов змогу проводити індивідуальні інструктажі. У межах системи управління навчанням цілі й завдання курсу є чітко викладеними та повинні бути легкими для пошуку студентами. Рівень оволодіння студентом мовою вимірюється відповідно до кожної мети й завдання. Зміст і завдання для основних онлайн курсів повинні бути чітко й ретельно узгодженими 3 державними академічними стандартами та рамками навчальних програм і стандартів оцінювання.

\section{АНОТАЦІЯ}

У статті визначено й проаналізовано особливості застосування онлайн інструментів у вивченні іноземних мов та оцінюванні якості знань студентів під час дистанційного навчання. Узагальнено інформацію щодо ефективного впровадження різноманітних інструментів, таких як система управління навчанням, GoogleDocs, модуль, мікролекторні відео, Google Календар, Nextcloud, Zoho, вебхостинг. Обгрунтовано застосування інструментів, які сприяють розвитку комунікативної компетентності студентів в іншомовному спілкуванні, серед яких є EventZilla, Open Conference Systems, 
Mobilizon i система веб-конференцій Zoom. У дослідженні встановлено, що оцінювання результатів оволодіння студентами іноземною мовою онлайн $є$ важливим і найскладнішим елементом здобуття якісної освіти. Для визначення ефективності оцінювання рівня знань студентів 3 іноземних мов охарактеризовано такі програми для дистанційного навчання, як TrainingCheck, ProProfs та iSpring Learn, що дають змогу перевіряти засвоєний студентами матеріал новими і творчими способами. Виявлено, що в програмі навчального курсу з іноземних мов для дистанційного навчання має бути чітко визначено цілі курсу й результати навчання студентів; завдання; очікування студентів; вимоги часу; необхідні матеріали; політика оцінювання; політика контактів учитель-студент, викладачвикладач; передбачувана аудиторія; зміст, обсяг матеріалу та послідовність його вивчення.

\section{ЛIТЕРАТУРА}

1. Creating an Online Community, Class or Conference - Quick Tech Guide / Google Docs. 2020. URL: https://docs.google.com/document/u/0/d/ 1ux31TnUTpzZRuvxE3rAsSQ4Ihub96S8_OYECNh8wv-A/mobilebasic\# heading $=$ h.xpjunkqt5jka.

2. Darby F. How to be a better online teacher. Advice Guide/ The Chronicle of Higher Education. Washington, D.C., 2020. URL: https://www.chronicle.com/interactives/advice-online-teaching.

3. E-xcellence in e-learning. Associates in Quality/ EADTU. Maastricht. The Netherlands, 2009. URL: https://e-xcellencelabel.eadtu.eu/.

4. Hedge S. Teaching with GoogleDocs/ A Blog from GradHacker and MATRIX: The Center for Humane Arts, Letters and Social Sciences Online. Washington, D.C., 2013. URL: https://www.insidehighered.com/blogs/ gradhacker/teaching-googledocs.

5. McIntyre S. Learning to teach online. Conducting effective online discussions / COFA Online. Australian Learning and Teaching Council, 2018. URL: https://tto.unsw.edu.au/wp-content/uploads/2018/03/ Discussions_LTT On.pdf.

6. Pomerantz J.D., Brooks C. Study of Faculty and Information Technology/ Educause Survey. ECAR, October, 2017. URL: https://library.educause.edu/resources/2017/10/ecar-study-of-faculty-andinformation-technology-2017.

7. Student Assessment Software. Easily create and share online tests and assessments / ProProfs. Quiz Maker. 2005-2020. URL: https://www.proprofs.com/quiz-school/solutions/student-assessment-software/. 
8. Swiftly Moving to Teaching Online - Resource Bank/ National Institute for Digital Learning. Dublin, 2020. URL: https://www.dcu.ie/nidl/ resources/Swiftly-Moving-Online-Coronavirus.shtml.

9. Welcome to ACUE's online teaching toolkit/ Association of College and University Educators. New York, 2020. URL: http://acue.org/onlineteaching-toolkit/.

\section{Information about the authors:}

Strelchenko L. V.,

Ph.D. in Pedagogic Sciences, Associate Professor, Lecturer at the Department of Ukrainian Language Donetsk National Medical University 4A, Kovalenko str., Kropyvnytskyi, Ukraine

Dudina O. V., Lecturer at the Department of Languages and Humanities Donetsk National Medical University 4A, Kovalenko str., Kropyvnytskyi, Ukraine 